\title{
THE DENTIST IN MODERN MILITARY ORGANIZATION.
}

\author{
By Capt. W. F. Wolvern, Dental Corps, U. S. A.
}

(Read before a Meeting of the Sall Francison Unit of Preparedness League of American Dentists.)

In opening this paper I do not think that I can do better than quote the following from a paper read by Dr. Wallace Seccombe, of Toronto, Canada, before the Buffalo Dental Society, in September, 1916.

"The word that most nearly describes modern military organization is efficiency. In striving for efficiency in the fighting forces, a scientific study of motion is made, with a view to elimination of waste time and energy. Modern methods of drill are the result. One hears much in these days of war equipment and mechanism, guns and ammunition. But after all the determining factor remains the same, namely, the human element. Wars are won or lost, armies win ultimate success or failure, depending, in the final analysis, upon the physical condition and mental attitude of the troops. It is this personal element that makes right, might. Thus the standard is applied to the individual soldier as well as to the organization and equipment of the army. The successful army officer attaches the greatest importance to the morals of his men, and never fails to arrange for their comfort, happiness, and contentment, in order that good physical, mental and moral conditions may be maintained.

"In the modern army, separate corps or branches are organized to give special eare and attention to the personal needs of the men. In the United States Army, the quartermaster's department looks after the food, clothing, transportation, etc., and the medical department attends to the camp hygiene and the sick and wounded."

In addressing you, gentlemen, it is unnecessary for me to $d$ well at length upon the importance of dental service in main- taining the health and comfort of the individual soldier. The army dentist is never looked upon by the military authorities as absolutely essential. The importance of the civilian dentist to the general public is generally recognized and appreciated and in comparison the army dentist is vastly more important to the soldier in time of war.

Permit.me to refer briefly to a few of the reasons why the dental surgeon is of outstanding importance to the army. The life and health of the average soldier is of more value to the state in time of war than that of the average civilian. There is greater demand for dental services in the army than there is among a corresponding number of civilians, owing to the varying conditions of climate, exposure and diet, to which the soldier is exposed, and which render him more susceptable to dental pain and disease. When a soldier is incapacitated thru any cause, the fighting forces of the army are not only lowered to that extent, but the sick man instead of being a help becomes an actual burden, because of the attention necessary upon the part of others, in nursing him back to health. There is also in the modern trench warfare, a greater frequency to injury about the face and jaws, making the presence of the dental surgeon advisable, in a comparatively large percentage of the cases requiring surgical treatment.

If further argument were necessary one might refer to the terrific bombardments and sustained artillery duels characteristic of present day warfare, and the resulting strain upon the nervous system, and the consequent necessity for keeping the soldier in the best condition of health.

The absolute need for adequate dental 
service in the army is beyond question and that this service must be of the most efficient is also beyond question.

The Dental Corps in the U. S. Army is a part of the Medical Department and is under the direct control of the Surgeon General of the Army. Assignments to station are made upon recommendation of the Surgeon General or the Surgeon of a military department. All instruments and supplies are purchased and distributed by the Medical Department. Congress in providing for a Dental Corps, stated that there should be one dental surgeon of each one one thousand of the enlisted strength of the lines of the army. This actually means that there are about fifteen hundred men for each dental surgeon, for the staff-the quartermaster's corps, the medical corps, signal corps, etc., are of course entitled to treatment as well as the line.

Under the act of June 3, 1916, the dental surgeons are given the commissioned grades, Major, Captain and 1st Lieuten: ant. After serving eight years as a 1st Lieutenant, a dental surgeon is, after passing an examination, promoted to the grade of Captain, and after a total ser vice of twenty-four years, fifteen of the dental surgeons may be promoted Major, after examination.

Dental surgeons with the rank of 1st Lieutenant, receive a base pay of $\$ 2,000$ a year. Those with rank of Captain receive $\$ 2,400$ and those with the rank of Major, $\$ 3,000$. Each of these grades, however, receive increase of 10 per cent of the above amounts, in addition for every five years of service. In addition to his pay, a dental surgeon is entitled to quarters, fuel and light and medical and dental attention. $\mathrm{He}$ also receives a baggage allowance, when changing stations and mileage at a rate of seven cents when traveling under military orders. Dental surgeons, after serving 35 years, or after reaching the age of sixty-four, or after becoming physically unfit, in line of duty, are retired from active duty and receive three-fourths of the pay of grade held by them on the date of retirement.

A dental surgeon is required to serve officers and enlisted men, contract surgeons, members of the army. nurse corps, prisoners of war, and other persons in military custody or confinement, and applicants for enlistment when held under observation. Also when practicable, the families of officers and enlisted men, and at stations, or in the field where other dental attention cannot be secured, civilian employees. The enlisted men are not entitled to any work requiring the use of gold. With-this exception there is nothing in dentistry or dental surgery that is not required of the dental surgeon. You may have your specialist in civil life, but the idea is to get the best all around man for the army. Of course not all kinds of work are done at all times. The man in the field, for instance, who is equipped with a field outfit, does not do the same work that the man in the post does, nor does the man in the post do the same kind of work as is required of one at what is known as a base station, where the full equipment of a dental surgeon is supplied. The dental surgeon, however, is expected to be capable of doing the dental work required of him anywhere, in the field, in the post, or at a base station.

The duties of the dental surgeon are not confined to his professional work as a dentist. As a commissioned officer of the army, he may be ordered to duty, on a court martial for the trial of officers or enlisted men. He may be detailed for duty on any of the various kinds of boards, or as counsel for men undergoing trial. His command, however, is limited to members of the dental corps.

Boards for the examination of candidates for appointment in the dental corps, are appointed by the Adjutant General of the Army, ani consist of one Medical officer and two Dental officers. The examination consists of two parts, 1st Physical, and 2nd, Professional. In the physical examination the condition of the 
body and the organs, is gone over thoroly, by the medical member of the board. The professional examination consists of both oral and written questions on theory and a practical chemical examination. The oral examination includes, oral surgery, operative dentistry, and prosthetic dentistry. The subjects of the written examination are, anatomy, physiology and histology, materia-medica and therapeutics, dental pathology and bacteriology, chemistry, physics and metallurgy. The clinical examination is of such a character as will thoroly test the candidates practical knowledge of operative and prosthetic dentistry. An average mark of 75 per cent is required to qualify in the subjects of the oral and written examinations, and 85 per cent in the practical examination. The board also examines into the moral character and general fitness for the service of the candidate. Candidates who qualify are recommended by the board for a commission by the President. Examinations are held whenever, in the opinion of the Surgeon Gen- eral, they are necessary and not at stated intervals.

At the present time and under the law now in force, there is authority for one hundred and seventeen dental surgeons, of this number there is actually in the service at the present time eighty-six, nineteen of this number having the rank of Captain and sixty-seven that of 1st Lieutenant. This leaves thirty-one vacancies to be filled. However, as you all know, Congress is at work on national defense measures, and whatever bill finally becomes a law will affect the dental corps as well as the other branches of the service. The General Staff, universal service bill, for instance, which provides for an army of 500,000, also provides for a corps of dental surgeons of 500 , divided among the three grades of Major, Captain and 1st Lieutenant. Another bill, however, while it provides for about the same number of dental surgeons-1 to 1,000 of the enlisted strength-gives the additional grades of Lt. Colonel and Colonel. In any event, a good many dental surgeons are going to be needed at once.

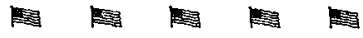 \\ ADDRESS OF MAJOR P. S. BOND,* CLEVE- LAND, OHIO.}

(Given before the Cleveland Dental Society, April 2nd, 1917.)

I was invited here tonight to talk to you for a few minutes upon the connection between dentistry and defense. It is not necessary for me to add any details to the example Governor Herrick gave you showing how an ulcerated tooth affected the destiny of the Western Hemisphere.

*Major P. S. Bond is a graduate of West Point, and has been in the service of his country twentyone years. At times of Peace, he takes up great Engineering Problems, and is at the present time located in Cleveland as Federal Engineer, and has charge of all the improvements and work on the rivers and harbors. He has done good work for Cleveland and promises us a million population by 1920.-Dr. F. M. Casto, Cleveland, ohio.
The modern conception of war is one that few of us appreciate, but it calls into activity every artisan and practitioner of every art that we have knowledge of. The first requirement of a soldier is that he have an excellent physique and the connection between good teeth and good health I think is so plain that it requires no explanation at all. When I was in the Philippine Islands I had a Company of soldiers and too many of them were on the sick list. I worried a good deal about it and came to the conclusion that their troubles were large- 